CM. S. Khmil ${ }^{1,3}$, B. M. Ventskivskyi ${ }^{2}$, S. V. Khmil ${ }^{1,3}$

${ }^{1}$ I. Horbachevsky Ternopil National Medical University

${ }^{2} \mathrm{O}$. Bohomolets National Medical University

${ }^{3}$ Medical Center "Professor Stefan Khmil Clinic"

\title{
MODERN APPROACHES TO THE TREATMENT OF INFERTILITY IN WOMEN WITH POLYCYSTIC OVARIAN SYNDROME IN ASSISTED REPRODUCTIVE TECHNOLOGY PROGRAMS
}

The aim of the study - to improve infertility treatment by optimizing pregravid therapy and selecting the optimal stimulation protocol and ovulation trigger in patients with PCOS.

Materials and Methods. 157 infertile patients with PCOS were examined. Depending on the method of treatment, patients were divided into three clinical groups. Group 1 consisted of 63 women who received FT 500-Plus and vitamin $D_{3}$ Aquadetrim for 2-3 months before stimulation, group 2-48 women who received folic acid, group 3-46 women who did not receive pregravid preparation. Stimulation was conducted with corifolitropin-alpha Elonva according to a short protocol, GnRH antagonist Orgalutran and follicle-stimulating hormone Puregon, as a trigger $\mathrm{GnRH}$ agonist Diphereline was used (in groups 2 and $3-0.2 \mathrm{mg} / \mathrm{ml}$ once, and in group 1 the protocol was modified by us: $0.2 \mathrm{mg} / \mathrm{ml}+$ an additional $0.1 \mathrm{mg} / \mathrm{ml}$ after 12 hours). The effectiveness of the proposed infertility treatment regimen was assessed by the following indicators: the frequency of complications, in particular OHSS, the total percentage of efficiency of the obtained oocytes, the degree of maturity of the oocytes obtained and the yield of blastocysts.

Results and Discussion. When evaluating the results of superovulation induction, it was found that the duration of stimulation in group 1 was probably lower compared to groups 2 and 3. On the day of the ovulation trigger, a significantly lower concentration of estradiol and progesterone was found in group 1, compared with the data of other groups. In study group 1, where the introduction of the ovulation trigger was modified in own way, significantly fewer immature (GV and MI) oocytes were found, while the average number of mature eggs significantly exceeded the data of groups 2 and 3 . The number of blastocysts in women with infertility on the background of PCOS group 1 was also significantly higher than the results obtained in other groups.

Conclusions. Controlled ovarian stimulation according to a short protocol using a vitamin complex with inositol and vitamin $\mathrm{D}_{3}$ in pregravid preparation and gonadotropin-releasing hormone antagonists and GnRH agonist trigger -Diphereline at a dose of $0.2 \mathrm{mg} / \mathrm{ml}+0.1 \mathrm{mg} / \mathrm{ml}$ after 12 hours is more effective in the program of assisted reproductive technologies in PCOS, as it increases the number of mature cells (by $12.20 \%$ ) and blastocysts (by $16.26 \%$ ). It is also safer because its use significantly reduces the incidence of ovarian hyperstimulation syndrome $(1.6 \%)$ in women with infertility with PCOS compared to other controlled ovarian stimulation (COS) regimens.

Key words: infertility; inositol; gonadotropin-releasing hormone antagonist; polycystic ovary syndrome; in vitro fertilization.

\section{СОВРЕМЕННЫЕ ПОДХОДЫ К ЛЕЧЕНИЮ БЕСПЛОДИЯ У ЖЕНЩИН С СИНДРОМОМ ПОЛИКИСТОЗНЫХ ЯИЧНИКОВ} В ПРОГРАММЕ ВСПОМОГАТЕЛЬНЫХ РЕПРОДУКТИВНЫХ ТЕХНОЛОГИЙ

Цель исследования - усовершенствовать лечение бесплодия путем оптимизации прегравидарной терапии и выбора оптимального протокола стимуляции и триггера овуляции у пациенток с СПКЯ.

Материалы и методы. Обследовано 157 бесплодных пациенток с СПКЯ. В зависимости от метода лечения больные были разделены на три группы: I (первую) составили 63 женщины, которые получали «FT 500-Plus» и витамин $\mathrm{D}_{3}$ «Аквадетрим» в течение 2-3 месяцев до стимуляции, II (вторая) - 48 женщин, получавших фоолиевую кислоту, III (третья) - 46 женщин, которым не проводилась прегравидарная подготовка. Стимуляцию осуществляли корифролитропином-альфра - «Элонва» по короткому протоколу, антагонистом ГнРГ - «Оргалутран» и фолликулостимулирующим гормоном «Пурегон», в качестве триггера использовали агонист ГнРГ - «Диферелин» (во II и III группах: 0,2 мг/мл однократно, а в I группе протокол был модифицирован нами: 0,2 мг/мл + дополнительно 0,1 мг/мл через 12 ч). Эфреективность предложенной схемы лечения бесплодия оценивали по следующим показателям: частота развития осложнений, в частности синдрома гиперстимуляции яичников, суммарный процент эффективности полученных ооцитов, степень зрелости ооцитов и выход бластоцист.

Результаты исследования и их обсуждение. При оценке результатов индукции суперовуляции установлено, что продолжительность стимуляции в I группе была достоверно ниже по отношению к II и III группам. В день триггера овуляции было выявлено достоверно более низкую концентрацию эстрадиола и прогестерона в I группе относительно данных других групп. В I опытной группе, где введение триггера овуляции было модифицировано в собственный способ, выявлено достоверно меньше незрелых (GV и MI) ооцитов, тогда как среднее количество зрелых яйцеклеток достоверно превышало данные II и III групп. Количество бластоцист у женщин с бесплодием на фоне СПКЯ I группы также было достоверно выше по сравнению с полученными результатами в других группах.

Выводы. Контролируемая овариальная стимуляция по короткому протоколу с использованием витаминного комплекса с инозитолом и витамином $\mathrm{D}_{3}$ в прегравидарной подготовке и антагонистов гонадотропин-рилизинг-гормона и триггера агониста ГнРГ - «Диферелин» в дозе 0,2 мг/мл + 0,1 мг/мл через 12 ч эффективнее в программе вспомогательных репродуктивных технологий при СПКЯ, поскольку увеличивает количество зрелых клеток (на 12,20 \%) и бластоцист (на 16,26 \%). Этот протокол также является более безопасным, поскольку его использование существенно снижает частоту возникновения синдрома гиперстимуляции яичников (1,6 \%) у женщин с бесплодием на фоне Спкя относительно других схем КОС. 
Ключевые слова: бесплодие; инозитол; антагонист гонадотропин-рилизинг гормона; синдром поликистозных яичников; экстракорпоральное оплодотворение.

\section{СУЧАСНІ ПІДХОДИ ДО ЛІКУВАННЯ БЕЗПЛІДДЯ У ЖІНОК ІЗ СИНДРОМОМ ПОЛІКІСТОЗНИХ ЯЄЧНИКІВ У ПРОГРАМІ ДОПОМІЖНИХ РЕПРОДУКТИВНИХ ТЕХНОЛОГІЙ}

Мета дослідження - удосконалити лікування безпліддя шляхом оптимізації прегравідарної терапії і вибору оптимального протоколу стимуляції та тригера овуляції у пацієнток із СПКя.

Матеріали та методи. Обстежено 157 безплідних пацієнток із СПкя. Залежно від методу лікування хворих було поділено на три групи: I (першу) склали 63 жінки, які отримували «FT 500-Plus» та вітамін $\mathrm{D}_{3}$ «Аквадетрим» протягом 2-3 місяців до стимуляції, II (друга) - 48 жінок, які отримували сролієву кислоту, III (третя) - 46 жінок, яким не проводили прегравідарну підготовку. Стимуляцію здійснювали корифолітропіном-альфа - «Елонва» за коротким протоколом, антагоністом ГнРГ «Оргалутран» та фролікулостимулюючим гормоном «Пурегон», як тригер використовували агоніст ГнРГ - «Дисререлін» (в II i III групах: 0,2 мг/мл одноразово, а в I групі протокол був модифрікований нами: 0,2 мг/мл + додатково 0,1 мг/мл через 12 год). Есрективність запропонованої схеми лікування безпліддя оцінювали за такими показниками: частота розвитку ускладнень, зокрема СГЯ, сумарний відсоток ефективності отриманих ооцитів, ступінь зрілості ооцитів та вихід бластоцист.

Результати дослідження та їх обговорення. При оцінці результатів індукції суперовуляції встановлено, що тривалість стимуляції у I групі була вірогідно нижчою стосовно II і III груп. У день тригера овуляції було виявлено вірогідно нижчу концентрацію естрадіолу й прогестерону в I групі стосовно даних інших груп. У І дослідній групі, де введення тригера овуляції було модисіковано у власний спосіб, виявлено вірогідно менше незрілих (GV i MI) ооцитів, тоді як середня кількість зрілих яйцеклітин достовірно перевищувала дані II і III груп. Кількість бластоцист у жінок із безпліддям на фроні Спкя I групи також була вірогідно вища порівняно з отриманими результатами в інших групах.

Висновки. Контрольована оваріальна стимуляція за коротким протоколом із використанням вітамінного комплексу з інозитолом і вітаміном $\mathrm{D}_{3}$ у прегравідарній підготовці та антагоністів гонадотропін-рилізинг-гормону та тригера агоніста ГнРГ - «Диферелін» в дозі 0,2 мг/мл + 0,1 мг/мл через 12 год є ефективнішою у програмі допоміжних репродуктивних технологій при СПкЯ, оскільки збільшує кількість зрілих клітин (на 12,20 \%) та бластоцист (на 16,26 \%). Цей протокол також $€$ безпечнішим, оскільки його використання суттєво знижує частоту виникнення синдрому гіперстимуляції яєчників (1,6 \%) у жінок із безпліддям на фоні СПкя стосовно інших схем КОС.

Ключові слова: безпліддя; інозитол; антагоніст гонадотропін-рилізинг-гормону; синдром полікістозних яєчників; екстракорпоральне запліднення.

INTRODUCTION. Today, infertility is one of the most urgent medical and social problems in modern obstetrics, gynecology, reproductive medicine in Ukraine, as well as around the world [1]. An increasing number of married couples in the treatment of infertility use assisted reproductive technologies, which are currently the most effective method in the treatment of this pathology. Endocrine infertility occupies an important place in the structure of infertile marriage, as this form is more often primary and is characterized by polymorphism of clinical and laboratory manifestations. A common feature for all forms of endocrine infertility is anovulation [2]. It accounts for about $40 \%$ of all forms of female infertility [3]. Polycystic ovary syndrome (PCOS) is one of the most common causes of anovulatory infertility $[4,5]$.

PCOS is a polysyndromic disease often associated with infertility and the most common pathology in women of reproductive age, both in Ukraine and abroad. According to the literature, PCOS is diagnosed in almost $50 \%$ of women with menstrual and ovulatory disorders, and in $40 \%$ of patients with endocrine infertility. The incidence of PCOS in women of reproductive age is $6-20 \%$. It is noted that more than 100 million women aged 15 to 49 have PCOS [4-10].

Assisted reproductive technologies (ART) are the main ways to restore fertility in patients with PCOS.

The key to achieve the result is the right approach to diagnosis, pregravid preparation, pregnancy planning and the choice of infertility treatment.

In recent years, it has been reported that the use of inositol-containing drugs is a new and effective method of treating women with infertility associated with ovarian scleropolycystosis, improves the quality of life of PCOS patients by eliminating metabolic disorders and improving the expected results of infertility treatment. As a result of inositol treatment, menstrual disorders are restored, the quality of eggs and embryos is improved, which, in turn, increases the frequency of pregnancy. However, there is much debate today about its effectiveness compared to other drugs used to treat women with PCOS, which requires more detailed study.

The effect of vitamin $D_{3}$ on a woman's fertility has been intensively studied in recent decades. A large amount of data indicates a beneficial effect of vitamin $D_{3}$ on metabolic and hormonal disorders in polycystic ovary syndrome and the effectiveness of infertility treatment in programs of assisted reproductive technologies [11-12]. The use of vitamin $D_{3}$ in the treatment of infertility associated with polycystic ovary syndrome is of particular interest [13-14]. Recently, there are more and more studies on the effects of vitamin $D_{3}$ on ovulatory dysfunction, androgenic status and IVF results, and the course of pregnancy in women with PCOS.

Thus, to date, there is a large number of scientific publications on protocols for controlled ovulation stimulation in patients with polycystic ovary syndrome, but the data presented in them require systematization, improvement and refinement of pregravid preparation and selection of the optimal stimulation protocol and ovulation trigger for, and would reduce the likelihood of hyperstimulation syndrome, which is what our work is dedicated

THE AIM OF THE STUDY is to improve the treatment of infertility by optimizing pregravid therapy and selecting the optimal stimulation protocol and ovulation trigger in patients with polycystic ovary syndrome.

MATERIALS AND METHODS. A clinical examination of 157 infertile women with polycystic ovary syndrome was conducted, who were offered various methods of pregravid preparation before controlled ovarian stimulation (COS) in in 
vitro fertilization (IVF) programs. Depending on the method of treatment, patients were divided into three clinical groups.

Experimental group 1 consisted of 63 women with infertility associated with PCOS (40.1\%), who before controlled ovulation stimulation received combination therapy of FT 500 plus vitamin complex one sachet once a day for 2-3 months and Aquadetrim vitamin $D_{3}$ in average therapeutic doses of 2 drops 2-3 times a day for 2-3 months.

Experimental group 2 consisted of 48 infertile women with PCOS (30.6\%), who received folic acid $(400 \mu \mathrm{g})$ daily for 2-3 months before and during controlled stimulation of superovulation before puncture of follicles with oocyte aspiration.

Experimental group 3 consisted of 46 women with infertility associated with PCOS (29.3\%), who did not receive pregravid preparation.

Controlled ovarian stimulation was performed according to a short protocol using recombinant gonadotropin corifollitropin alfa Elonva. Indications for the treatment of patients with polycystic ovary syndrome using assisted reproductive technologies (ART) were a combination of PCOS and tubal-peritoneal factor infertility and/or impaired spermatogenesis in men, no pregnancy after 3-5 attempts to induce ovulation with clomiphene citrate.

Thus, in three study groups, patients underwent controlled ovarian stimulation with a new hormonal drug, which belongs to a new class of recombinant long-acting gonadotropins - corifollitropin alfa Elonva. Compared to standard recombinant $\mathrm{FSH}$, corifollitropin alfa has twice the half-life. All this allows you to stimulate the growth of follicles for 7 days after a single subcutaneous injection. On day 8 after Elonva administration, superovulation was stimulated with recombinant Puregon FSH until the oocytes matured (size of 3 follicles $\geq 18 \mathrm{~mm}$ ). To prevent the ovulatory peak of luteinizing hormone on day 5-7 of stimulation, depending on the initial response of the ovaries to stimulation, when the size of the follicles reached at least $14-15 \mathrm{~mm}$, we prescribed gonadotropin-releasing hormone antagonist
(GnRH) Organultran 0.25 mg daily subcutaneously. Gonadotropin-releasing hormone antagonists suspend the synthesis of gonadotropins by blocking pituitary receptors without affecting their number. The use of antGnRg should be prescribed a few days before the appearance of the parasitic peak of luteinizing hormone.

According to ultrasound and hormonal monitoring, the duration of COS and drug doses, as well as the introduction of the ovulation trigger were determined. GnRH agonist Diphereline was used as a trigger (in groups 2 and 3 $0.2 \mathrm{mg} / \mathrm{ml}$ once, and in group 1 the protocol was modified by us, so after 12 hours this drug was additionally administered at a dose of $0.1 \mathrm{mg} / \mathrm{ml}$ ). Generalized stimulation protocols of patients with polycystic ovary syndrome are presented in Fig. 1.

A puncture of the follicles with aspiration of oocytes was conducted 35-36 $\mathrm{h}$ after the introduction of the ovulation trigger under general anesthesia. Fertilization of eggs and cultivation of embryos with subsequent vitrification on the 5th day (blastocyst stage) was performed in an IVF laboratory. Evaluation of oocytes was performed after denudation, before the ICSI procedure. The meiotic state of oocytes (GV, MI, MII) was evaluated. In IVF/ICSI cycles, the assessment was performed according to morphological parameters: valuation of the transparent membrane (zona pellucida), changes in the size and shape of the oocyte itself, quality, characteristics of the perivithelin space, the state of the polar body. Fertilization results were assessed 16-19 h after ICSI procedure, fragmentation rates, and blastocyst yield on day 3 and 5-6. Qualitative characteristics of embryos at the blastocyst stage was performed according to the Gardner system [15].

The level of progesterone and estradiol was determined by enzyme-linked immunosorbent assay in the laboratory of the Medical Center "Professor Stefan Khmil Clinic" (accreditation No. 268604/2019).

The effectiveness of the proposed regimen of infertility treatment was evaluated by the following indicators: the frequency of complications, in particular OHSS, the total

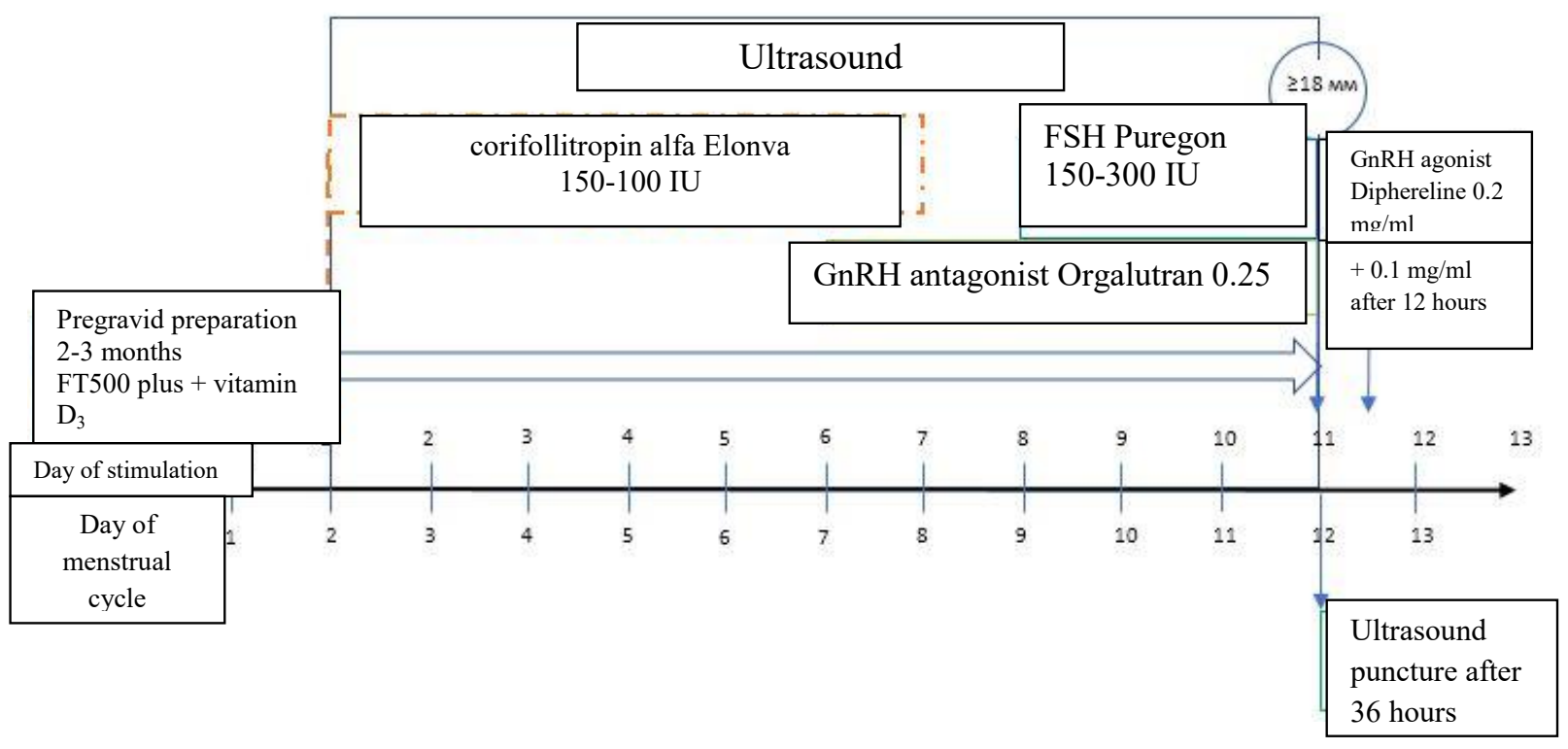

Fig. 1. Stimulation protocols for patients with polycystic ovary syndrome. 
percentage of efficiency of the oocytes obtained, the degree of maturity of oocytes and the yield of blastocysts.

Statistical analysis of the results of the study was performed using Microsoft Office Excell and Statistica computer software. The choice of the method of obtained data analysis was based on the number of groups included in the survey, the correctness of the distribution of values in them, as well as the equality of variances. The description of quantitative characteristics, which were subject to the normal distribution of values (according to the obtained nomograms and Shapiro-Wilk and Lilliefors normality criteria), was carried out in the form of Mean $\pm S D$ (standart deviation). With the wrong distribution of values, they were represented as $\mathrm{Me}(\mathrm{Lq} ; \mathrm{Uq})$ (medians of both the lower and upper quartiles). The frequency characteristics of the studied indicators were described as absolute value (n), percentage (\%) and $95 \% \mathrm{Cl}$ (confidence interval).

RESULTS AND DISCUSSION. Analysis of the structure of concomitant diseases of the reproductive system showed that in all groups the frequency of combination with male infertility factor, tubal-peritoneal and combined male factor + tubal-peritoneal infertility is probably not different (Table 1 ). It should also be noted that most often patients of all groups were diagnosed with PCOS in combination with male infertility factor $-52(33.1 \%)$ patients.

The study of the structure of concomitant somatic diseases showed that patients with PCOS and infertility are dominated by gynecological operations in the anamnesis (75 people) and metabolic syndrome (46 people), the lowest frequency of combination of PCOS with diabetes (6 women), Fig. 1. It should be noted that in some patients several concomitant pathologies were registered.

The analysis of gynecological surgical interventions in patients with PCOS depending on the type of pregravid preparation showed some differences (Table 2). Thus, in the group of women undergoing pregravid preparation with folic acid, the lowest frequency of gynecological surgeries was diagnosed (8.3 \% - laparotomy and $10.4 \%$ - laparoscopy), while in the group of women undergoing pregravid preparation with vitamin complex FT 500 Plus almost equally in the anamnesis these surgical interventions were revealed.

Table 1. Distribution of patients with polycystic ovary syndrome depending on the cause of infertility

\begin{tabular}{|c|c|c|c|c|c|c|c|}
\hline \multirow[t]{2}{*}{ Infertility cause } & \multirow[t]{2}{*}{ Absent/present } & \multicolumn{2}{|c|}{$\begin{array}{c}\text { Group } 1 \\
(n=63) \text { modified cos } \\
\text { regimen }\end{array}$} & \multicolumn{2}{|c|}{$\begin{array}{c}\text { Group } 2 \\
(\mathrm{n}=48) \text { standard COS } \\
\text { regimen }\end{array}$} & \multicolumn{2}{|r|}{$\begin{array}{l}\text { Group } 3 \\
(\mathrm{n}=46) \\
\text { control }\end{array}$} \\
\hline & & $\mathrm{N}$ & $\begin{array}{c}\% \\
(95 \% \mathrm{Cl}) \\
\end{array}$ & $\mathrm{n}$ & $\begin{array}{c}\% \\
(95 \% \mathrm{Cl}) \\
\end{array}$ & $\mathrm{n}$ & $\begin{array}{c}\% \\
(95 \% \mathrm{Cl}) \\
\end{array}$ \\
\hline \multirow[t]{2}{*}{$\begin{array}{l}\mathrm{PCOS}+\text { tubular- } \\
\text { peritoneal factor }\end{array}$} & Absent & 49 & $\begin{array}{c}77.78 \\
(65.02 ; 92.29) \\
\end{array}$ & 38 & $\begin{array}{c}79.17 \\
(65.74 ; 88.27) \\
\end{array}$ & 32 & $\begin{array}{c}69.57 \\
(55.20 ; 80.92) \\
\end{array}$ \\
\hline & Present & 14 & $\begin{array}{c}22.22 \\
(17.71 ; 24.98)\end{array}$ & 10 & $\begin{array}{c}20.83 \\
(11.73 ; 34.26)\end{array}$ & 14 & $\begin{array}{c}30.43 \\
(19.08 ; 44.80)\end{array}$ \\
\hline \multirow[t]{2}{*}{$\begin{array}{l}\text { PCOS + male } \\
\text { factor }\end{array}$} & Absent & 44 & $\begin{array}{c}69.84 \\
(57.64 ; 79.76) \\
\end{array}$ & 28 & $\begin{array}{c}58.33 \\
(44.28 ; 71.15) \\
\end{array}$ & 33 & $\begin{array}{c}71.74 \\
(57.45 ; 82.68) \\
\end{array}$ \\
\hline & Present & 19 & $\begin{array}{c}30.16 \\
(20.24 ; 42.36) \\
\end{array}$ & 20 & $\begin{array}{c}41.67 \\
(28.85 ; 55.72) \\
\end{array}$ & 13 & $\begin{array}{c}28.26 \\
(17.32 ; 42.55) \\
\end{array}$ \\
\hline \multirow{2}{*}{$\begin{array}{c}\text { PCOS + male and } \\
\text { tubal-peritoneal } \\
\text { factor }\end{array}$} & Absent & 54 & $\begin{array}{c}85.71 \\
(69.30 ; 91.10)\end{array}$ & 42 & $\begin{array}{c}87.50 \\
(75.30 ; 94.14)\end{array}$ & 35 & $\begin{array}{c}76.09 \\
(62.07 ; 86.09) \\
\end{array}$ \\
\hline & Present & 9 & $\begin{array}{c}14.29 \\
(8.90 ; 21.70) \\
\end{array}$ & 6 & $\begin{array}{c}12.50 \\
(5.86 ; 24.70) \\
\end{array}$ & 11 & $\begin{array}{c}23.91 \\
(13.91 ; 37.93) \\
\end{array}$ \\
\hline \multirow[t]{2}{*}{ PCOS only } & $\begin{array}{l}\text { other factors are not } \\
\text { taken into account }\end{array}$ & 47 & $\begin{array}{c}74.60 \\
(62.66 ; 83.72) \\
\end{array}$ & 36 & $\begin{array}{c}75.00 \\
(61.22 ; 85.08) \\
\end{array}$ & 38 & $\begin{array}{c}82.61 \\
(69.28 ; 90.92) \\
\end{array}$ \\
\hline & PCOS only & 16 & $\begin{array}{c}25.40 \\
(16.28 ; 37.34) \\
\end{array}$ & 12 & $\begin{array}{c}25.00 \\
(14.92 ; 38.78)\end{array}$ & 8 & $\begin{array}{c}17.39 \\
(9.08 ; 30.72) \\
\end{array}$ \\
\hline
\end{tabular}

Note. For all causes of infertility $p>0.05$ (confidence level for $x 2$ ).

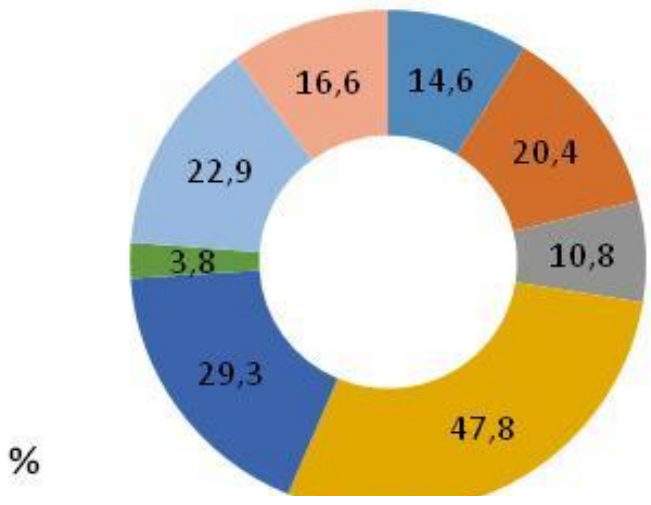

neurological diseases

neuropsychological stress

primary injuries

gynecological operations

metabolic syndrome

type 2 diabetes

infectious diseases

endometrial hyperplasia

Fig. 1. Distribution of concomitant somatic diseases in women with PCOS and infertility included in the study (\%). 
Table 2. Frequency of gynecological surgical interventions in patients with PCOS depending on the type of pregravid preparation

\begin{tabular}{|c|c|c|c|c|c|c|}
\hline \multirow[b]{2}{*}{ Gynecological operation } & \multicolumn{2}{|c|}{ Group $1(n=63)$ modified COS regimen } & \multicolumn{2}{|r|}{ Group $2(n=48)$} & \multicolumn{2}{|c|}{ Group 3(n=46) } \\
\hline & $\mathrm{N}$ & $\begin{array}{c}\% \\
\text { \% } \\
(95 \mathrm{Cl})\end{array}$ & $\mathrm{n}$ & $\begin{array}{c}\% \% \\
(95 \% \mathrm{Cl})\end{array}$ & $n$ & $\begin{array}{c}\% \\
(95 \% \mathrm{Cl})\end{array}$ \\
\hline Absent & 29 & $\begin{array}{c}46.03 \\
(34.31 ; 58.21) \\
\end{array}$ & 39 & $\begin{array}{c}81.25 \\
(68.06 ; 89.81)^{\star \star}\end{array}$ & 14 & $\begin{array}{c}30.43 \\
(19.08 ; 44.80) \\
\end{array}$ \\
\hline Laparotomy & 18 & $\begin{array}{c}28.57 \\
(18.90 ; 40.70)\end{array}$ & 4 & $\begin{array}{c}8.33 \\
(3.29 ; 19.55)^{\star *}\end{array}$ & 18 & $\begin{array}{c}39.13 \\
(26.39 ; 53.54)\end{array}$ \\
\hline Laparoscopy & 16 & $\begin{array}{c}25.40 \\
(16.28 ; 37.34) \\
\end{array}$ & 5 & $\begin{array}{c}10.42 \\
(4.53 ; 22.17)^{\star \star}\end{array}$ & 14 & $\begin{array}{c}30.43 \\
(19.08 ; 44.80) \\
\end{array}$ \\
\hline
\end{tabular}

Note. ${ }^{* *}-p<0.001$ (confidence level for $\chi^{2}$ ).

Analysis of BMI of patients included in the study showed a uniform distribution of women with normal weight, overweight and obesity of various degrees in the experimental groups (Table 3). It was found that 53 patients had a normal weight, respectively, 40 - overweight and 64 - obesity of varying degrees.

According to the type of fat distribution, $7.6 \%$ of women included in the study had a gluteofemoral (gynoid) type, and $29.3 \%$ - abdominal (android) type of obesity. The distribution of patients by type of fat distribution did not differ in the experimental groups (Table 4).

A comprehensive assessment of clinical and anamnestic data of women with a verified diagnosis of "female infertility, polycystic ovary syndrome", who were included in the study, indicates a predominance of women aged 30-34 years with a duration of infertility up to 5 years, which was $82.8 \%$ of patients; among concomitant pathologies, PCOS was most often combined with the male factor (33.1\% of women). Analysis of the anamnestic parameters of patients with infertility on the background of PCOS indicates previous attempts to stimulate ovulation with Clostilbegyt (100.0\%), intrauterine insemination (34.4\%) and in vitro fertilization (16.6\%). The analysis of clinical and anthropometric factors indicates the homogeneity of the experimental groups.
Patients were offered the following protocols for ovulation stimulation (Table 5). When evaluating the results of superovulation induction, it was found that the duration of stimulation in group 1 was probably lower in relation to group $2(6.88 \%)$ and 3 (5.88\%), which indicates the effect of pregravid preparation with inositol and vitamin $D_{3}$ on the degree of follicle maturation (Table 5). The reduction in duration of stimulation in group I is probably due to the effect of pre-pregnancy training on the faster response to follicle-stimulating hormone stimulation. The reduction in duration of stimulation in group 1 is probably due to the effect of pregravid preparation on the faster response to folliclestimulating hormone stimulation.

The total dose of gonadotropins in patients of the experimental groups was small, but the lowest doses were prescribed to women with PCOS, who underwent pregravid preparation with inositol and vitamin $\mathrm{D}_{3}$ (Table 5).

It was found that in women with infertility associated with PCOS as a result of COS for a short protocol after pregravid preparation, the average number of follicles $\geq 18 \mathrm{~mm}$ and endometrial thickness in the experimental groups probably did not differ. On the day of the ovulation trigger, a significantly lower concentration of estradiol was found in group 1, relative to the data of groups 2 (1.14 times) and 3 (1.20 times). The

Table 3. Distribution of patients depending on body mass index

\begin{tabular}{|c|c|c|c|c|c|c|}
\hline \multirow[t]{2}{*}{ Obesity degree (WHO classification) } & \multicolumn{2}{|c|}{$\begin{array}{c}\text { Group } 1(\mathrm{n}=63) \text { modified COS } \\
\text { regimen }\end{array}$} & \multicolumn{2}{|c|}{ Group $2(\mathrm{n}=48)$} & \multicolumn{2}{|c|}{ Group $3(n=46)$} \\
\hline & $\mathrm{n}$ & $\%$ & $\mathrm{n}$ & $\%$ & $\mathrm{n}$ & $\%$ \\
\hline $\begin{array}{l}\text { Normal body weight (BMI 20.0-24.9 } \\
\mathrm{kg} / \mathrm{m}^{2} \text { ) }\end{array}$ & 16 & 25.40 & 19 & 39.58 & 18 & 39.13 \\
\hline Overweight (BMI 25.0-29.9kg/m²) & 18 & 28.57 & 12 & 25.00 & 10 & 21.74 \\
\hline $\begin{array}{l}\text { Obesity } \\
\text { Degree } 1 \text { (BMI 30.0-34.9 kg/m²) }\end{array}$ & 14 & 22.22 & 7 & 14.58 & 8 & 17.39 \\
\hline $\begin{array}{l}\text { Obesity } \\
\text { Degree } 2 \text { (BMI } 35.0-39.9 \text { kg/m²) }\end{array}$ & 10 & 15.87 & 6 & 12.50 & 7 & 15.22 \\
\hline $\begin{array}{l}\text { Obesity } \\
\text { Degree } 3\left(\mathrm{BMI}>40 \mathrm{~kg} / \mathrm{m}^{2}\right)\end{array}$ & 5 & 7.94 & 4 & 8.33 & 3 & 6.52 \\
\hline
\end{tabular}

Table 4. Dividing of patients by type of fat distribution

\begin{tabular}{|l|c|c|c|c|c|c||}
\hline \multirow{2}{*}{ Type of fat distribution } & \multicolumn{2}{|c|}{ Group 1 $(\mathrm{n}=63)$ modified COS regimen } & \multicolumn{2}{c||}{ Group 2 $(\mathrm{n}=48)$} & \multicolumn{2}{c|}{ Group 3 $(\mathrm{n}=46)$} \\
\cline { 2 - 7 } & $\mathrm{n}$ & $\%$ & $\mathrm{n}$ & $\%$ & $\mathrm{n}$ & $\%$ \\
\hline Female & 35 & 55.56 & 31 & 64.58 & 33 & 71.74 \\
\hline Android & 23 & 36.51 & 13 & 27.08 & 10 & 21.74 \\
\hline Gynoid & 5 & 7.94 & 4 & 8.33 & 3 & 6.23 \\
\hline
\end{tabular}


Акушерство та гінекологія

Table 5. Protocols of controlled ovarian stimulation in patients with polycystic ovary syndrome, $\mathbf{n = 1 5 7}$

\begin{tabular}{|l|c|c|c|}
\hline \multicolumn{1}{|c|}{ Indication } & $\begin{array}{c}\text { Group 1 (n=63) modified COS } \\
\text { regimen }\end{array}$ & Group 2 (n=48) & Group 3 (n=46) \\
\hline $\begin{array}{l}\text { corifollitropin alfa Elonva } \\
\text { patient weight } \geq 60 \mathrm{~kg} \\
\text { patient weight } \leq 60 \mathrm{~kg}\end{array}$ & $150 \mathrm{IU}$ & $150 \mathrm{IU}$ & $100 \mathrm{IU}$ \\
\hline $\begin{array}{l}\text { The average additional dose of } \\
\text { recombinant gonadotropin (rFSH) } \\
\text { Puregon MO from day 8 }\end{array}$ & $100 \mathrm{IU}$ & $750 \pm 90.8 \mathrm{IU}$ & $760 \pm 105.5 \mathrm{IU}$ \\
\hline $\begin{array}{l}\text { GnRH antagonist 0.25 mg Orgalutran } \\
\text { GnRH agonist 0.2 mg/ml Diphereline }\end{array}$ & $0.25 \mathrm{mg}$ & $0.25 \mathrm{mg}$ & $0.25 \mathrm{mg}$ \\
\hline $\begin{array}{l}\text { GnRH agonist 0.2 mg/ml Diphereline } \\
\text { after 12 hours 0.1 mg/ml }\end{array}$ & $0.1 \mathrm{mg} / \mathrm{ml}$ & $0.2 \mathrm{mg} / \mathrm{ml}$ & $0.2 \mathrm{mg} / \mathrm{ml}$ \\
\hline Stimulation duration & $10.15 \pm 0.18^{\star *}$ & - & - \\
\hline
\end{tabular}

Notes. 1. * - probable difference between groups 1 and $3(p>0.05)$;

2. \# - probable difference between groups 1 and 2 ( $p>0.05)$.

concentration of progesterone in the serum was statistically lower in group 1 relative to the data of groups 2 (1.50 times) and 3 (1.75 times) (Table 6).

During aspiration, the number of oocytes obtained did not differ significantly in the experimental groups with respect to control. The percentage of GV oocytes in group 1 was $6.8 \%$, in group $2-13.9 \%$, in group $3-14.9 \%$; the percentage of immature $\mathrm{Ml}$ oocytes was $10.1 \%, 16.1 \%$ and $17.3 \%$, respectively, and the percentage of mature $\mathrm{MI}$ II oocytes was $83.1 \%, 70.0 \%$ and $68.0 \%$, respectively. Thus, in the experimental group 1 , where the introduction of the ovulation trigger was modified in the own way, there were found significantly fewer immature (GV and MI) oocytes, while the average number of mature eggs significantly exceeded the data of group 2 (1.22 times) and group 3 (1.30 times). The number of blastocysts in women with infertility associated with PCOS in group 1 was probably higher compared with the results obtained in groups 2 (16.26 \%) and 3 (20.12\%). It should be noted that the analysis of indicators that characterize the oocytes obtained and embryos in patients of group 2 did not show significant differences with respect to the values of group 3 (Table 7). The results of the effectiveness of the use of vitamin complex with inositol and vitamin $\mathrm{D}_{3}$ in pregravid preparation and gonadotropinreleasing hormone antagonists and $\mathrm{GnRH}$ agonist trigger Diphereline at a dose of $0.2 \mathrm{mg} / \mathrm{ml}+0.1 \mathrm{mg} / \mathrm{ml}$ after 12 hours in the COS protocol, can be explained primarily by the action of inositol derivatives involved in the formation of

Table 6. Characteristics of folliculogenesis on the day of ovulation trigger (Mean \pm SD)

\begin{tabular}{|l|c|c|c||}
\hline \multicolumn{1}{|c|}{ Parameters } & $\begin{array}{c}\text { Group 1 } \\
(\mathrm{n}=63) \text { modified COS regimen }\end{array}$ & $\begin{array}{c}\text { Group 2 } \\
(\mathrm{n}=48)\end{array}$ & $\begin{array}{c}\text { Group 3 } \\
(\mathrm{n}=46)\end{array}$ \\
\hline $\begin{array}{l}\text { The number of follicles with a diameter } \\
\text { of } \geq 18 \mathrm{~mm}\end{array}$ & $31.19 \pm 6.90$ & $31.45 \pm 7.20$ & $32.19 \pm 7.80$ \\
\hline Endometrial thickness $(\mathrm{mm})$ & $10.4 \pm 1.60$ & $9.80 \pm 1.80$ & $10.70 \pm 1.20$ \\
\hline Progesterone levels $(\mathrm{ng} / \mathrm{ml})$ & $0.80 \pm 0.22^{*}$ & $1.20 \pm 0.18$ & $1.40 \pm 0.24$ \\
\hline Estradiol values $(\mathrm{pg} / \mathrm{ml})$ & $1820 \pm 61.25^{\star \wedge}$ & $2070 \pm 64.45$ & $2190.00 \pm 54.15$ \\
\hline
\end{tabular}

Note. * - the probable difference between groups 1 and $3(p>0.05)$;

$\wedge$ - the probable difference between groups 1 and $2(p>0.05)$

Table 7. Feature of the oocytes and embryos obtained in comparison groups in women with infertility associated with PCOS (Mean \pm SD)

\begin{tabular}{|c|c|c|c|}
\hline Indicators & $\begin{array}{c}\text { Group } 1(\mathrm{n}=63) \\
\text { modified COS regimen }\end{array}$ & $\begin{array}{c}\text { Group } 2 \\
(\mathrm{n}=48) \text { standard COS } \\
\text { regimen }\end{array}$ & $\begin{array}{c}\text { III група } \\
\text { (n=46) } \\
\text { control }\end{array}$ \\
\hline The average number of oocytes obtained & $21.35 \pm 6.5$ & $20.85 \pm 7.1$ & $20.15 \pm 7.4$ \\
\hline The average number of GV oocytes & $\begin{array}{c}1.45 \pm 0.81 \text { *\# } \\
(6.8 \%)\end{array}$ & $\begin{array}{l}2.9 \pm 0.70 \\
(13.9 \%) \\
\end{array}$ & $\begin{array}{l}3.0 \pm 0.60 \\
(14.9 \%) \\
\end{array}$ \\
\hline The average number of immature M I oocytes & $\begin{array}{c}2.15 \pm 0.36^{*} \# \\
(10,1 \%)\end{array}$ & $\begin{array}{c}3.36 \pm 0.51 \\
(16.1 \%)\end{array}$ & $\begin{array}{c}3.48 \pm 0.62 \\
(17.3 \%) \\
\end{array}$ \\
\hline $\begin{array}{l}\text { The average number of mature } \\
\text { M II oocytes }\end{array}$ & $\begin{array}{c}17.75 \pm 1.19^{\star} \# \\
(83.1 \%)\end{array}$ & $\begin{array}{c}14.59 \pm 1.24 \\
(70.0 \%)\end{array}$ & $\begin{array}{c}13.67 \pm 1.36 \\
(68.0 \%)\end{array}$ \\
\hline The number of blastocysts & $6.15 \pm 0.35^{\star} \#$ & $5.29 \pm 0.24$ & $5.12 \pm 0.15$ \\
\hline
\end{tabular}

Notes. 1. * - probable difference between groups 1 and $3(p>0.05)$;

2. \# - probable difference between experimental groups 1 and $2(p>0.05)$. 
calcium-mediated signals from gonadotropin receptors that activate cells at the time of fertilization [16]. Secondly, the use of gonadotropin-releasing hormone agonist as an ovulation trigger is more physiological during oocyte maturation - it initiates the release of luteinizing hormone within 24 hours, so we proposed the use of additional trigger at a dose of $0.1 \mathrm{mg} / \mathrm{ml}$, which we consider more optimal for this category of patients.

In the patients we examined in group 1 mild OHSS was detected in 1 (1.6\%) patient, in group $2-3(6.3 \%)$, and in control group $3-2(4.3 \%)$ patients. According to scientists, against the background of the use of inositol the concentration of estradiol on the day of ovulation trigger decreases, which reduces the risk of developing OHSS [17]. This is also confirmed by the results of our study. Patients did not require hospital admission, were treated on an outpatient basis. To date, the replacement of the ovulation trigger by a $\mathrm{GnRH}$ agonist is the most effective method of OHSS prevention.

CONCLUSIONS. Controlled ovarian stimulation according to a short protocol using a vitamin complex with inositol and vitamin $\mathrm{D}_{3}$ in pregravid preparation and gonadotropinreleasing hormone antagonists and $\mathrm{GnRH}$ agonist trigger Diphereline at a dose of $0.2 \mathrm{mg} / \mathrm{ml}+0.1 \mathrm{mg} / \mathrm{ml}$ after 12 hours is more effective in the program of assisted reproductive technologies in PCOS, as it increases the number of mature cells (by $12.20 \%$ ) and blastocysts (by $16.26 \%$ ). It is also safer because its use significantly reduces the incidence of ovarian hyperstimulation syndrome (1.6\%) in women with infertility associated with PCOS compared to other COS regimens.

PROSPECTS FOR FURTHER RESEARCH. In the future, it is planned to compare the frequency of fertilization in different regimens of pregravid preparation of women with PCOS, for whom controlled ovarian stimulation was performed by a short protocol.

\section{LITERATURE}

1. Юзько О. М. Подолання безпліддя за допомогою репродуктивних технологій / О.М.Юзько, Т. А. Юзько // Медичн аспекти здоров'я жінки. - 2009. - № 3 (20). - С. 50-55.

2. Тюрина Н. А. Причины женского бесплодия / Н. А. Тюрина, Ю. Ф. Сайсретдинова // Огарёв-Online. - 2014. - № 12.

3. Манушарова Р. А. Бесплодный брак/Р. А. Манушарова // Эфффективная фрармакотерапия. Эндокринология. - 2014. № 1 (9). - С. 34-39.

4. Гуриев Т. Д. Синдром поликистозных яичников / Т. Д. Гуриев // Акушерство, гинекология и репродукция. 2010. - № 4 (2). - С. 10-15.

5. Назаренко Т. А. Синдром поликистозных яичников. Современные подходы к диагностике и лечению бесплодия / T. А. Назаренко // Moscow: MEDpress-inform. -2008. - С. 208.

6. Natural molecules for the therapy of hyperandrogenism and metabolic disorders in PCOS / V. Capelli, M. C. Musacchio, A. Bulfoni [et al.] // Eur. Rev. Med. Pharmacol. Sci. - 2017. Vol. 21 (2). - P. 15-29.

7. Comparision of myo-inositol versus metformin on anthropometric parameters in polycystic ovarian syndrome in women / J. Nehra, J. Kaushal, S. R. Singhal, V. S. Ghalaut // Int. J. Pharm. Pharm. Sci. - 2017. - Vol. 9 (4). - P. 144-148.

8. Polycystic ovary syndrome / U. A. Ndefo, A. Eaton, M. Robinson Green // Pharm. Ther. - 2013. - Vol. 38 (6). - P. 336-355.

9. Pasquali R. Management of endocrine disease: Secondary Polycystic Ovar Syndrome: theoretical and practical aspects / R. Pasquali, E. Diamanti-Kandarakis, A. Gambineri // Eur. J. Endocrinol. - 2016. - Vol. 175 (4). - P. 157 R.169.

\section{REFERENCES}

1. Yuzko, O.M., \& Yuzko, T.A. (2009). Podolannia bezpliddia za dopomohoiu reproduktyvnykh tekhnolohii [Overcoming infertility with the help of reproductive technologies]. Medychni aspekty zdorovia zhinky - Medical aspects of womens health 3 (20), 50-55 [in Ukrainian].

2. Tyurina, N.A., \& Sayfetdinova, Yu.F. (2014). Prichiny zhenskogo besplodiya [Causes of female infertility]. OgarevOnline, 12 [in Russian].

3. Manusharova, R.A. (2014). Besplodnyy brak [Barren marriage]. Effektivnaya farmakoterapiya. Endokrinologiya - Effective pharmacotherapy. Endocrinology, 1 (9), 34-39 [in Russian].

4. Guriyev, T.D. (2010). Sindrom polikistoznykh yaichnikov
10. Lifestyle and environmental contributions to ovulatory dysfunction in women of polycystic ovary syndrome / B. Zhang, W. Zhou, Y. Shi [et al.] // BMC Endocr. Disord. - 2020. - Vol. 20 (1). - P. 19.

11. Relevance of vitamin D in reproduction / J. Luk, S. Torrealday, G. N. Perry, L. Pal. // Hum. Reprod. - 2012. - Vol. 27 (10). - P. 3015-3027.

12. Association of vitamin $D$ intake and serum levels with fertility: results from the Lifestyle and Fertility Study / J. L. Fung, T. J. Hartman, R.L. Schleicher, M. B. Goldman // Fertil. Steril. 2017. - Vol. 108 (2). - P. 302-311.

13. Effect of vitamin $D$ supplementation on polycystic ovary syndrome: A meta - analysis / C.-Y. Miao, X.-J. Fang, Y. Chen, Q. Zhang // Exp. Ther. Med. - 2020. - Vol. 19 (4). - P. 2641-2649.

14. Lin M. W. The role of vitamin $D$ in polycystic ovary syndrome / M. W. Lin, M. H. Wu // Indian J. Med. Res. - 2015. - Vol. 142 (3). - P. 238-240.

15. Hardarson T. The blastocyst / T. Hardarson, L. Van Landuyt, G. Jones // Human. Reprod. - 2012. - Vol. 27 (1). - P. 72-91.

16. Чернуха Г. Е. Механизмы формирования инсулинорезистентности при синдроме поликистозных яичников и терапевтические эффректы мио-инозитола / Г. Е. Чернуха, М. А. Удовиченко, А. А. Найдукова // Гинекология. - 2019. № 1 (66). - С. 55-60.

17. Wdowiak A. Myoinositol improves embryo development in PCOS patients undergoing ICSI / A. Wdowiak // Int. J. Endocrinol. - 2016. - (13). - P. 1-8.

[Polycystic ovary syndrome]. Akusherstvo, Ginekologiya $i$ Reproduktsiya - Obstetrics, Gynecology and Reproduction, 4 (2), 10-15 [in Russian].

5. Nazarenko, T.A. (2008). Sindrom polikistoznykh yaichnikov. Sovremenniye podkhodi k diagnostike i lecheniyu besplodiya [Syndrome of polycystic ovaries. Modern approaches to the diagnosis and treatment of infertility]. Moscow: MEDpressinform [in Russian].

6. Cappelli, V., Musacchio, M.C., Bulfoni, A., Morgante, G., \& De Leo, V. (2017). Natural molecules for the therapy of hyperandrogenism and metabolic disorders in PCOS. Eur. Rev. Med. Pharmacol. Sci., 21 (2), 15-29. 
7. Nehra, J., Kaushal, J., Singhal, S.R., \& Ghalaut, V.S. (2017). Comparision of myo-inositol versus metformin on anthropometric parameters in polycystic ovarian syndrome in women. Int. J. Pharm. Pharm. Sci., 9 (4), 144-148.

8. Ndefo, U.A., Eaton, A., \& Robinson, M. (2013). Green polycystic ovary syndrome. Pharm. Ther., 38 (6), 336-355.

9. Pasquali, R., Diamanti-Kandarakis, E., \& Gambineri, A. (2016). Management of endocrine disease: Secondary Polycystic Ovar Syndrome: theoretical and practical aspects. Eur. J. Endocrinol., 175 (4), 157 R.169.

10. Zhang, B., Zhou, W., Shi, Y., Zhang, J., Cui, L., \& Chen, Z.-J. (2020). Lifestyle and environmental contributions to ovulatory dysfunction in women of polycystic ovary syndrome. BMC Endocr. Disord., 20 (1), 19.

11. Luk, J., Torrealday, S., Perry, G.N., \& Pal, L. (2012). Relevance of vitamin D in reproduction. Hum. Reprod., 27 (10), 3015-3027.

12. Fung, J.L., Hartman, T.J., Schleicher, R.L., \& Goldman, M.B.
(2017). Association of vitamin D intake and serum levels with fertility: results from the Lifestyle and Fertility Study. Fertil. Steril., 108 (2), 302-311.

13. Miao, C.-Y., Fang, X.-J., Chen, Y., \& Zhang, Q. (2020). Effect of vitamin $D$ supplementation on polycystic ovary syndrome: A meta - analysis. Exp. Ther. Med., 19 (4), 2641-2649.

14. Lin, M.W., \& Wu, M.H. (2015). The role of vitamin D in polycystic ovary syndrome. Indian J. Med. Res., 142 (3), 238-240.

15. Hardarson, T., Van Landuyt, L., \& Jones, G. (2012). The blastocyst. Human. Reprod., 27 (1), 72-91.

16. Chernukha, G.Ye., Udovichenko, M.A., \& Naydukova, A.A. (2019). Mekhanizmy formirovaniya insulinorezistentnosti pri sindrome polikistoznykh yaichnikov i terapevticheskiye effekty mio-inozitola. Ginekologiya - Gynecology, 1 (66), 55-60 [in Russian].

17. Wdowiak, A. (2016). Myoinositol improves embryo development in PCOS patients undergoing ICSI. Int. J. Endocrinol., 13, 1-8.

Отримано 15.05.20 Прийнято до друку 17.06.20 Електронна адреса для листування: klinika_khmil@ukr.net 